\title{
EGY LOKÁLIS ÉLETMINŐSÉG INDEX KIALAKÍTÁSÁNAK LÉPÉSEI
}

\author{
TAKÁCS PÉter - FÁbián Gergely
}

\begin{abstract}
Well-being positions and relations of persons or smaller/bigger human groups can be expressed by "quality of life" indicators. The related examinations are important for comparing various comminuties (countries, regions, etc.) - both in time and in space. Values of indexes indicate the positive or negative features of the humanactivities. The indexes can sign various trends connecting withchanges of the quality of comminities's life.The content of the paper is the following. Firstly, general indexes whichare used by researchers are summarized. These indexes can measure the quality of life relations in national level. Common features of these indexes are the connection to a single scientific research area (for example economy, health, psychology, etc.) In the develomment of this subject (of these indexes), the researhers have begun to associate the single indexes, create complex variables.

Secondly, we show our research about creating a local quality of life index - connecting to the Háztartáspanel (household panel survey) examinations in Nyíregyháza. We show two models and the connected researches. The second model measures the wellbeing relations in the area of regional-, urban- or in smaller communities. We can state, researches and calculations reflex the well-being relations of Nyíregyháza in according to other researches.
\end{abstract}

Keywords: Nyíregyháza household panel survey, local quality life index DOI: $10.19055 / \mathrm{ams} .2012 .3 / 3 / 4$

\section{BEVEZETÉS}

Az életminőség mutatók számokkal fejezik ki egyének, vagy kisebb/nagyobb csoportok általános jóléti helyzetét, életminőségi viszonyait. A mutatókhoz kapcsolódó elemzések fontos szerepet töltenek be a különbözö közösségek (országok, régiók, stb. ) öszszehasonlításában mind térben, mind időben. Az indexértékek jelzik az emberi tevékenységek eredményeként fellépő elöremutató pozitív vonásokat, vagy a visszahúzó negatív tendenciákat - a közösségek életminőség változásait. 
Ebben a dolgozatban elöször vázlatosan összefoglaljuk azokat a mutatókat, amelyek általában nemzeti szinten képesek mérni életminöségi viszonyokat. Közös jellemzöik ezeknek az indexeknek a kezdeti szakmaspecifikusság. Egy-egy szükebb szakmakörből (gazdaság, egészségügy, pszichológia, szociológia, stb.) indulva alakították ki őket a kutatók. A kutatások fejlődése során a komplexebb mutatók kimunkálása lett a cél.

A dolgozat második részében a nyíregyházi Háztartáspanel vizsgálatokhoz kapcsolódó lokális életminőség index kialakításának két modelljét és néhány kapcsolódó elemzést ismertetünk. A kidolgozott életminőség index az országos és regionális közösségnél kisebb, városi szinten méri a lakosság jóléti viszonyait. Az eddig elvégzett számítások és elemzések alapján elmondhatjuk, hogy ez a lokális mutató jól tükrözi Nyíregyháza városáról kialakult képet; összhangban van más, témaspecifikusabb vizsgálatok eredményeivel, napjaink változásaival.

Az eredmények bemutatása során nem csak a letisztult, véglegesített képet tárjuk az olvasók elé. Közlünk néhány olyan statisztikai részletet, magyarázatot és részeredményt is, amelyek bővebb betekintést engednek a kutatás munkafolyamatába, az index kialakításába.

\section{AZ ÉLETMINŐSÉG ÁLTALÁNOS MUTATÓI}

A fejlett társadalmakban a huszadik század második felétől társadalom- és gazdaságpolitika szintjén a figyelem középpontjába került az életminőség kérdése. Az alapgondolat maga az, hogy az egész társadalom legfontosabb célja kell, hogy legyen az emberi életminőség folyamatos növelése. A cél elérése érdekében meg kell alkotni azt az eszközrendszert, elméleti módszertani alapokat, amelyekkel vizsgálhatóbbá, objektívebbé tehetjük az életminőség fogalmát. Igen régi, alapvető kérdést feszegetnek ezek a vizsgálatok, hiszen életünk minősége mellett rögtön felmerül annak értelme, értékes volta - filozófiai mélységekbe víve a kutatókat.

Alapvetően két, egymástól élesen el nem különíthető komponensre bonthatjuk az életminőség fogalmát. Az egyik az objektív rész (GDP, születéskor várható átlagos élettartam, egészségben eltöltött évek száma, stb.), a másik pedig a szubjektíven megítélhető rész (élet-elégedettségi kérdések, kérdőíves felmérések).

Másik osztályozási szempontrendszer szerint az életminőség vizsgálatok alapmodelljei a gazdaságtudományhoz, a szociológiához, a pszichológiához és az egészségtudományokhoz köthetők. Ezek először szakma-specifikusan közelítették meg az emberi életminőség problémakörét, majd hiányosságaikat pótlandó, más területekről is integráltak értékelési szempontokat. Így alakultak ki mára azok a komplex mutatók, amelyekkel vizsgálhatóbbá válik a kérdés (HDI - Human Development Index, PQLI - Physical Quality of Life Index, HPI - Happy Planet Index, stb.).

Az érdeklődők számára jó kiindulási pontként említhetjük a magyar nyelven megjelent turisztikai életminőség-index szakirodalmi összefoglaló írását (Kovács, Horkay, Michalkó, 2006); a Wikipedia angol és magyar nyelvü forrásait, amelyeket sok esetben tartalmazzák az egyes indexek forrás-honlapjait - és magukat az index-értékeket is. 
Egy ország megítélése a különböző mutatók alapján igen eltérö lehet. A szakirodalom néhány forrása már jelzi, hogy megindult a törekvés a különböző mutatók szinkronizálására, az egyes indexek közötti kapcsolatok feltárására.

A következő fejezetben egy lokális életminőségi mutató kidolgozását ismertetjük, amely nem országos, vagy regionális szinten elemzi a jóléti viszonyokat, hanem városi szintre helyezi a vizsgálatokat.

\section{LOKÁLIS ÉLETMINŐSÉG INDEX}

2011-ben indítottuk el azt a vizsgálatot, amely egy városi szintű életminőség index kialakítását célozta meg. A kutatás a nyíregyházi Háztartáspanel vizsgálat 2008-as és 2010-es adatfelvételén alapult. Az elemzések során több életminőségi modellt is megvizsgáltunk.

Az elsőként bemutatandó modell egy egyszerü összegző modell, amely kumulálja a bevont változók mért értékeit. Ez a konstrukció a kutatási folyamat kezdeti eredményeit foglalja össze. Lényeges vonása, hogy általa sikerült kialakítanunk azt a változóhalmazt, amely a következő vizsgálat alapjául szolgált.

Második modellünkben egy összetettebb számítási folyamat révén alakítottunk ki életminőség indexet. Az első konstrukció huszonhárom kérdését hét csoportba soroltuk, majd fökomponens analízis segítségével határoztuk meg az egyes csoportok súlyát. A következő fejezetekben nemcsak a modell kialakításának részleteit ismertetjük, hanem bemutatunk néhány olyan elemzést is, amely már a kialakított indexek eloszlására, megoszlására vonatkozik.

\section{ÖSSZEGZŐ MODELL: 2008 ÉS 2010}

A bevonandó harminc változót a kutatás első szakaszában - mindkét év adataira vonatkozólag - átkódoltuk. Minden változó „,pozitív” értékeléssel szerepelt a továbbiakban, vagyis minden esetben úgy alakítottuk át a változókódolást, hogy a növekvő értékek növekvő, pozitív emberi megítélést tükrözzenek. Például a fizetéssel való megelégedéssel kapcsolatos változónkat (ház26) nem kellett átkódolnunk, mert a növekvő kódok a növekvő elégedettséget mérték („,1- csak nagy nehézségek árán jövünk ki belőle” ... „6 - nagyon jól kijövünk belőle"). Át kellett viszont alakítanunk például a barátokkal való találkozást mérő (társ13) változót, mert a nagyobb kód egy negatívabb hatást tükrözött („,1 - mindennap” ..., ,5-soha”). Hasonló módon jártuk el minden változó esetén.

Ezután a kódolt változókra vonatkozó leíró statisztikai elemzéseket végeztük el. Ennek eredményeként kizártunk három változót, amelyek válaszadási eredményei hiányosak voltak - nagyon sokan megtagadták a választ ezekben a kérdésekben, így nagyon lecsökkent volna a mutató kialakításába bevonható esetszám.

A harmadik szakaszban faktoranalízis-vizsgálat eredményeként újabb három változót kellett kizárnunk a további számításokból. Ezek a változók nem kapcsolódtak szorosan a változóhalmazhoz - kis értékủ kommunalitás (Székelyi, Barna, 2005). A meg- 
maradt huszonhárom változó képezte azt a kérdéshalmazt, amelynek összevonásával kialakítottuk az első modell életminőség indexét. A 2008-as változók esetén ez a következő volt (a változókhoz tartozó kérdések a mellékletben szerepelnek):

$$
\begin{aligned}
& \text { qli_sum_1 = társ } 1+\text { társ } 13+\text { társ } 13 \mathrm{~h} 2+\text { egál1 + gazd } 1+\text { gazd } 25+ \\
& \text { ház26 + ház19h3 + ház19h4 + ház19h8 + ház19h9 + társ11 + társ11h2 } \\
& \text { + társ11h3 + társ11h4 + társ11h5 + társ } 12+\text { társ } 28 \mathrm{~h} 3+\text { szocp } 1+ \\
& \text { szocp1h2 + szocp1h3 + szocp1h4 + szocp1h5 }
\end{aligned}
$$

A létrehozott qli sum 1 változót 577 esetre számítottuk. A be nem vont esetek száma 1291. Leíró statisztikai mutatók a következők. Átlag: 51,7558, medián: 50, módusz: 50, szórás: 14,56916, szórásnégyzet (variancia): 212,260.

Egy sok komponensből álló, összetett mutató eloszlása igen gyakran a normális eloszláshoz közelít. Kutatási terveink szerint normális eloszlású változó kialakítását céloztuk meg, ami a központi határeloszlás tételek szemléletéhez igazodva jogos elvárás lenne egy ilyen összetett változóval szemben. Több statisztikai próbát is elvégeztünk a normalitás igazolására. A Kolmogorov-Smirnov teszt és a Shapiro-Wilk teszt eredménye alapján a qli_sum_1 változó normalitása nem áll fenn. A számítások során a mindkét teszt esetén 0,05-nél jóval kisebb p értékeket kaptunk a (nullhipotézis: a vizsgált változó normális eloszlású; $\mathrm{p}=0,000$ ), így el kellett vetnünk a normalitásra vonatkozó null-hipotézisünket.

Megjegyzés: Statisztikai hipotézisek, próbák vizsgálatakor akkor követünk el elsőfajú hibát, ha eljárásunk igaz nullhipotézis elvetését eredményezi. A próba kritikus tartományát úgy szokás megválasztani, hogy az első fajta hiba valószínűsége ne haladja meg az ún. szignifikanciaszintet. Ez általában 0,05. Másodfajú hibát akkor követünk el, ha az ellenhipotézis igaz, de az eljárás mégis a nullhipotézis megtartását eredményezi. A számítógépes programcsomagok által is számított p-érték az elsőfajú hiba valószínüségét adja meg (a nullhipotézis elleni bizonyíték erősségének mértéke). Minél kisebb a p-érték, annál erősebb bizonyíték szól a nullhipotézis ellen. Ha p-érték kisebb vagy egyenlö, mint $0,05(\mathrm{p}<=0,05)$, akkor a nullhipotézist elvetjük. Amennyiben $\mathrm{p}$ nagyobb mint $0,05(\mathrm{p}>0,05)$, úgy a nullhipotézist megtartjuk. Egy megfigyelt hatást statisztikailag szignifikánsnak mondunk, ha a hatásra vonatkozó nullhipotézist el kell utasítanunk. Ez azt jelenti, hogy a jelenség bizonyíthatóan (meghatározott tévedési valószínűség mellett) nem a véletlen müve.

A qli_sum_1 változó gyakorisági eloszlása az 1. ábrán látható. A grafikon egy jobbra elnyúló eloszlást mutat, ami érthetővé teszi a normalitás-vizsgálat eredményeit.

A létrehozott új változóra alapozva további vizsgálatokat is végeztünk. Sok esetben igazolódott, hogy a normalitás hiánya a paraméteres és nemparaméteres vizsgálatok közötti különbséget magyarázza.

Megjegyzés: A paraméteres eljárásokat akkor alkalmaz a statisztika, a ismert a vizsgálatban szereplő változó eloszlása (például igazolni tudjuk, hogy a változó normális eloszlású). Ekkor a statisztikai eljárás többnyire az eloszlásra alapozva „müködik”. A nemparaméteres vizsgálatok esetén viszont nem szükséges az eloszlás ismerete. Egy fontos (de nem az egyetlen) módszere az ilyen vizsgálatoknak a rangsoroláson alapuló eljárások. Az adatokat (mintaelemeket) sorrendbe 
rakjuk; minden elemhez egyértelmüen hozzárendelünk egy sorszámot, majd ezekkel a sorszámokkal dolgozunk a továbbiakban. A fentebb szereplő normalitás-vizsgálat tehát az alkalmazható eljárások közötti választásban játszik döntő szerepet.

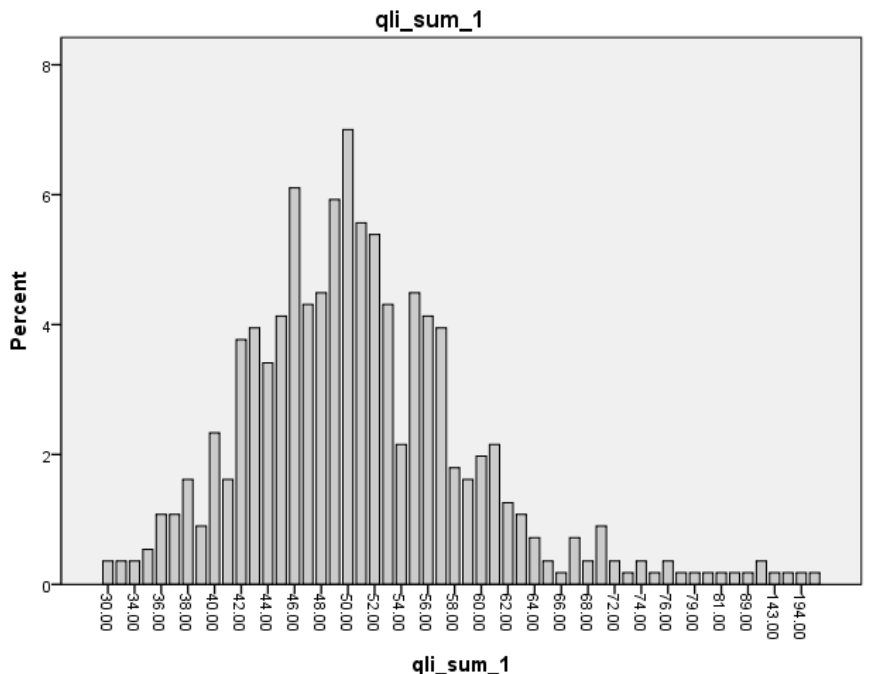

1. ábra - A 2008-as qli_sum_1 változó gyakorisági eloszlása.

Kerületek. Első lépésben Nyíregyháza város tizennégy részterületében (kerületek, „utca” változó) hasonlítottuk össze a qli_sum_1 életminőség mutató átlagértékeit. Az egyes részterületeken kitöltött kérdőívek számát és a százalékos megoszlást az 1. táblázat mutatja be.

Megjegyzés: A statisztikai feladat ebben a vizsgálatban a kérdéses csoportok (legalább három, vagy annál több) életminőség középértékeinek (átlagainak, mediánjainak) összevetése. Erre paraméteres eljárásként az egy-szempontos variancia-analízis alkalmas, amely több normális eloszlású, azonos varianciájú változó átlagának összehasonlítását teszi lehetővé. A t-próba valamely változatának többszöri alkalmazása nem ajánlott, mivel az elsőfajú hiba valószínüsége halmozódhat az ismétlések során. A variancia-analízisnek megfelelő nemparaméteres eljárás a Kruskal-Wallispróba, amely több független minta mediánjának egyenlőségét teszteli.

A kerületek összehasonlítása variancia-analízis alkalmazásával azt mutatja, hogy az egyes kerületek nem térnek el szignifikánsan (nullhipotézis: a kerületek életminőség középértékei egyenlők; $p=0,283$ alapján a nullhipotézist megtarthatjuk). Ez az eredmény a normalitási problémák miatt megkérdőjelezhető, így a Kruskal-Wallis nemparaméteres teszt eredményét kell elfogadnunk (nullhipotézis: a kerületek rangszámátlagai (életminőség mediánok) egyenlő nagyságúak; $\mathrm{p}=0,022$ ), amely szerint a kerületek 
átlagos életminőség indexei eltérők. Az egyes kerületek rangszámátlagait az 2. táblázat tartalmazza.

$\begin{array}{lcccc} & \text { Frequency } & \text { Percent } & \text { Valid Percent } & \text { Cumulative Percent } \\ \text { Oros } & 98 & 5.3 & 5.5 & 5.5 \\ \text { Örökösföld } & 203 & 11.0 & 11.4 & 16.9 \\ \text { Sóstó } & 130 & 7.0 & 7.3 & 24.3 \\ \text { Újkistelekiszőlő } & 64 & 3.5 & 3.6 & 27.9 \\ \text { Ókistelekiszölő } & 10 & .5 & .6 & 28.4 \\ \text { Borbánya } & 120 & 6.5 & 6.8 & 35.2 \\ \text { Huszártelep } & 24 & 1.3 & 1.4 & 36.5 \\ \text { Kertváros } & 118 & 6.4 & 6.6 & 43.2 \\ \text { Jósaváros I. } & 195 & 10.6 & 11.0 & 54.1 \\ \text { Jósaváros II. } & 56 & 3.0 & 3.2 & 57.3 \\ \text { Hímes } & 49 & 2.7 & 2.8 & 60.0 \\ \text { Belváros } & 537 & 29.1 & 30.2 & 90.3 \\ \text { Bokortanyák } & 110 & 6.0 & 6.2 & 96.5 \\ \text { Nyírszőlős } & 63 & 3.4 & 3.5 & 100.0 \\ \text { Total } & 1777 & 96.2 & 100.0 & \\ \text { Missing } & 71 & 3.8 & & \\ \text { Total } & 1848 & 100.0 & & \end{array}$

1. táblázat - A minta eloszlása Nyíregyháza részterületei szerint.

(SPSS output: Frequency -gyakoriság, Percent - \%, Valid Percent - összegzett \%, Cumulative Percent - kumulált \%, Missing - hiányzó, Total - teljes, összesen; tizedesvessző helyett itt tizedespont szerepel)

$\begin{array}{lrlc}\text { Kruskal-Wallis Test } & \text { qli_sum_1 } & & \\ \text { utca } & \mathrm{N} & \text { Mean Rank } & \text { Sorrend } \\ \text { Oros } & 30 & 296.32 & 6 . \\ \text { Örökösföld } & 71 & 225.04 & 12 . \\ \text { Sóstó } & 44 & 305.89 & 4 . \\ \text { Újkistelekiszőlő } & 17 & 252.74 & 10 . \\ \text { Ókistelekiszőlö } & 3 & 309.17 & 3 . \\ \text { Borbánya } & 31 & 310.56 & 2 . \\ \text { Huszártelep } & 5 & 87.10 & 14 . \\ \text { Kertváros } & 37 & 292.88 & 7 . \\ \text { Jósaváros I. } & 51 & 262.87 & 9 . \\ \text { Jósaváros II. } & 18 & 329.22 & 1 . \\ \text { Hímes } & 11 & 211.55 & 13 . \\ \text { Belváros } & 171 & 265.15 & 8 . \\ \text { Bokortanyák } & 31 & 252.44 & 11 . \\ \text { Nyírszölős } & 17 & 304.59 & 5 . \\ \text { Total } & 537 & & \end{array}$

2. táblázat - A minta eloszlása és a qli_sum_1 index Nyíregyháza részterületi szerint. (SPSS output: N - esetszám, Mean Rank - rangszámok átlagai, Total - összesen; tizedesvessző helyett itt tizedespont szerepel) 
A legmagasabb indexértékeket Jósaváros II, Borbánya; a legalacsonyabbat pedig Huszártelep kapta. Az általánosan kialakult „városkép” szerint előkelőbb helyen kellene szerepelnie például Sóstónak (4.) és Hímesnek (13.). Az esetszámok Ókistelekiszőlő és Huszártelep esetén igen kicsik, így ezek a kerületek esetlegesen kizárhatók lennének a vizsgálatból.

Rétegek. Összehasonlítást végeztünk a gazdasági vonatkozású megítélés („rétegek” változó) szerint is. Itt hasonlóan az előző vizsgálathoz, a variancia-analízis nem mutatott ki különbséget $(\mathrm{p}=0,279)$, de a normalitás hiánya miatt a Kruskal-Wallis teszt eredményét $(\mathrm{p}=0,000)$ kell ténylegesen elfogadnunk. A változó eloszlását a 3. táblázat mutatja be. Az (n) Mean Rank oszlop tartalmazza az egyes rétegekhez számított rangszámátlagokat is. Ezek rangszámátlagok a gazdasági megítélés növekedésével szintén növekedést (növekvő életminőség-index átlagot) mutatnak.

$\begin{array}{lccccc}\text { rétegek } & \text { Frequency } & \text { Percent } & \text { Valid Percent } & \text { Cumulative Percent } & \text { (n) Mean Rank } \\ \text { szegények } & 136 & 7.4 & 9.4 & 9.4 & \text { (26) } 207.35 \\ \text { alsó középréteg } & 405 & 21.9 & 28.0 & 37.4 & \text { (126) } 200.21 \\ \text { középréteg } & 474 & 25.6 & 32.8 & 70.1 & \text { (150) } 230.35 \\ \text { felső középréteg } & 365 & 19.8 & 25.2 & 95.4 & \text { (128) } 251.78 \\ \text { jómódúak } & 67 & 3.6 & 4.6 & 100.0 & \text { (37) } 321.08 \\ \text { Total } & 1447 & 78.3 & 100.0 & & \text { (467) } \\ \text { Missing System } & 401 & 21.7 & & & \\ \text { Total } & 1848 & 100.0 & & & \end{array}$

3. táblázat - A rétegek változó szerinti eloszlás.

(SPSS output: Frequency -gyakoriság, Percent - \%, Valid Percent - összegzett \%, Cumulative Percent - kumulált \%, Missing - hiányzó, Total - összesen, (n) - esetszám, Mean Rank - rangszámok átlagai; tizedesvessző helyett itt tizedespont szerepel)

Foglalkozás szerinti vizsgálat (gazd2 változó) hasonló képet tükrözött. A variancia-analízis nem mutatott ki különbséget $(\mathrm{p}=0,547)$, a Kruskal-Wallis teszt viszont igen $(\mathrm{p}=0,011)$. A normalitás hiánya miatt az utóbbi tesztet kell valósnak elfogadnunk, vagyis az egyes foglalkozási kategóriák életminőség indexei nem egyeznek meg. A sorrendeken alapuló teszt rangátlagait a 4. táblázat tartalmazza. A táblázat felhívja fi gyelmünket arra, hogy a vizsgált kérdéseknél a kategóriákba eső válaszadók száma igen lecsökkenhet, ami viszont éppen a nemparaméteres próbák alapkövetelményével (nagyobb elemszám) ellentétes. Ez az elemzés ténylegesen nem értékelhető. Jelen dolgozatban való szerepeltetése inkább figyelemfelkeltő és példaként szolgál; rámutatva egy statisztikai elemzés esetleges buktatóira.

$\begin{array}{lrlc}\text { Ranks } & & & \\ \text { az ön foglalkozása } & \text { Mean Rank } & \text { Sorrend } \\ \text { alkalmazott, teljes munkaidőben } & 438 & 276.98 & 6 . \\ \text { alkalmazott, részmunkaidőben } & 28 & 175.82 & 9 . \\ \text { GYES, GYED, GYET (van munkahelye) } & 9 & 297.94 & 4 . \\ \text { saját vállalkozásban dolgozik } & 52 & 298.56 & 3 . \\ \text { alkalmi munkából, megbízásokból él } & 5 & 278.30 & 5 .\end{array}$


eltartott, a családja támogatja

jövedelmeiből él

nyugdíjas

rokkantnyugdíjas

járadék, vagy nyugdíj mellett dolgozik

Total

$\begin{array}{rrr}1 & 469.00 & 1 . \\ 4 & 346.50 & 2 . \\ 3 & 191.50 & 8 . \\ 2 & 7.00 & 10 . \\ 4 & 262.38 & 7 . \\ 546 & & \end{array}$

4. táblázat - A foglalkozás (gazd2) változó szerinti eloszlás.

(SPSS output: N - esetszám, Mean Rank - rangszámok átlagai; tizedesvessző helyett itt tizedes pont szerepel)

Nyelvismeret. A megkérdezettek nyelvismerete (biogr9 változó) szerinti életminőség index eloszlása eltér az előző három eredménytől. Ennek bemutatását az 5. sz. táblázat tartalmazza. Az elvégzett kétmintás t-próba és a Mann-Whitney-féle U próba ugyanarra az eredményre vezetett. A nyelvismeret szempontjából a nyelvvizsgával rendelkezők szignifikánsan nagyobb indexmutatóval rendelkeznek, mint a másik részcsoport (t-próba $\mathrm{p}=0,025$, M-W U próba $\mathrm{p}=0,000)$.

Megjegyzés: A vizsgálatban a variancia-analízishez és a Kruskal-Wallis próbához hasonlóan csoportok középértékének összehasonlítása a cél. Két csoport esetén viszont az alkalmazandó paraméteres eljárás a kétmintás t-próba; nemparaméteres esetben pedig a Mann-Whitney-féle U próba.

$\begin{array}{llll}\text { Mann-Whitney Test } & & & \\ \text { rendelkezik-e ön nyelvvizsgával } & \mathrm{N} & \text { Mean Rank } & \text { Sum of Ranks } \\ \text { igen } & 143 & 343.46 & 49115.00 \\ \text { nem } & 402 & 247.94 & 99670.00 \\ \text { Total } & 545 & & \end{array}$

5. táblázat - A nyelvismeret szerinti eloszlás.

(SPSS output: Total - összesen, N - esetszám, Mean Rank - rangszámok átlagai, Sum of Ranks rangszámok összegei; tizedesvessző helyett itt tizedespont szerepel)

Személygépkocsi. Vizsgáltuk a személygépkocsi birtoklását is (6. sz. táblázat). A D, ponthoz hasonlóan itt is azonos eredményre vezetett a paraméteres kétmintás t-próba $(\mathrm{p}=0,006)$ és a nemparaméteres Mann-Whitney-féle $U$ teszt $(\mathrm{p}=0,000)$. A személygépkocsival rendelkezők szignifikánsan magasabb életminőség indexet tudhatnak magukénak, mint a gépkocsival nem rendelkezők.

$\begin{array}{llll}\text { van-e személygépkocsija } & \text { N } & \text { Mean Rank } & \text { Sum of Ranks } \\ \text { van } & 409 & 296.23 & 121156.50 \\ \text { nincs } & 146 & 226.94 & 33133.50 \\ \text { Total } & 555 & & \end{array}$

6. táblázat - A személygépkocsi birtoklása szerinti eloszlás.

(SPSS output: Total - összesen, N - esetszám, Mean Rank - rangszámok átlagai, Sum of Ranks rangszámok összegei; tizedesvessző helyett itt tizedespont szerepel) 
2010. A bemutatott elemzéseken kívül a 2008. évi adatok további feldolgozását is elvégeztük, majd rátértünk a 2010. évi adatok vizsgálatára. Hasonló módon alakítottuk ki a qli_sum_1 változót, mint a 2008-as évi adatok esetén. Végül csak 69 háztartás esetén volt mind a 23 kérdés értékelhető (a feldolgozás során 991 kieső háztartás).

Az úgynevezett , kiürülés jelensége” okán (a hiányzó válaszok halmozódása, a bevonható esetek csökkenése) nem folytattuk tovább az ilyen irányú vizsgálatokat, a már bemutatott másik modell kialakítását helyeztük elötérbe.

Összefoglalóan elmondhatjuk, hogy az Összegző modellel végzett munka számos érdekes és tanúságos mozzanatot hordoz magában. Ezek közül csak néhány pontokba szedve:

1. A nemparaméteres elemzések mutattak igazán szignifikáns különbséget a vizsgált változók esetén. A kicsi elemszám erősíti a kézikönyvekben olvasható kritériumot a normalitás ellenőrzésére vonatkozóan, amit még nagy mintaelemszám esetén is figyelembe kell vennünk.

2. Paraméteres és nemparaméteres módszerek alkalmazása megfelelő elemszám elérése (a válaszadási kategóriákban) esetén általában ugyanarra a következtetésre vezet.

3. A rangszámokon alapuló sorrendek általában eltérnek az átlagértéken alapuló sorrendektől.

4. Az Összegző modell alkalmas közelítő modellnek, de nem tükrözi teljes mértékben a városról kialakult képet a vizsgált viszonyokban pontosításra szorul. Több esetben is felmerül egyes változókategóriák igen kis elemszáma, ami a modell validitását egyes vizsgálatokban megkérdőjelezheti.

\section{A FÖKOMPONENS MODELL KIALAKÍTÁSA}

Az előző fejezetben összefoglalt pontokat figyelembe vételével léptünk tovább a vizsgálatokban. Második modellünk kiinduló pontjának Tauhidur Rahman által kidolgozott konstrukciót tekinthetjük (Rahman, Mittelhammer, Wandschneider, 2005). Ez a megközelítés olyan komplex életminőségi mutatót épít fel, amelyben nyolc részterületröl származó változóegyüttes alakítja ki az életminőség mérőszámát - 7. táblázat és 2 . ábra.

$\begin{array}{llll}\text { I. } & \text { Családi, baráti viszonyok } & \text { II. } & \text { Érzelmi jólét (nincs mérve) } \\ \text { III. } & \text { Egészségi állapot } & \text { IV. } & \text { Anyagi jólét } \\ \text { V. } & \text { Lokális közösség } & \text { VI. } & \text { Munka és aktivitás } \\ \text { VII. } & \text { Személyes biztonság } & \text { VIII. } & \text { Környezet minősége }\end{array}$

7. táblázat - A Rahman modell mérési részterületei.

Ezek a részterületek a modell input elemei, az output elemek olyan mutatók, mint például Várható Boldog Évek száma (Happy Life Expectancy); Az élettel való elégedettség indexe (Life Satisfaction Index); Egyenlőtlenséggel igazított boldogság indexe (Inequality Adjusted Happiness - IAH), stb. 
A teljes modell egy magyarra fordított összefoglaló ábráját közölte írásában Kovács Balázs, Sebestyén Tamás (Kovács, 2005; Sebestyén, 2005; Kovács, Horkay, Michalkó, 2006), amit itt mi is megismétlünk - 2. ábra.

Rahman életminôség-modellje

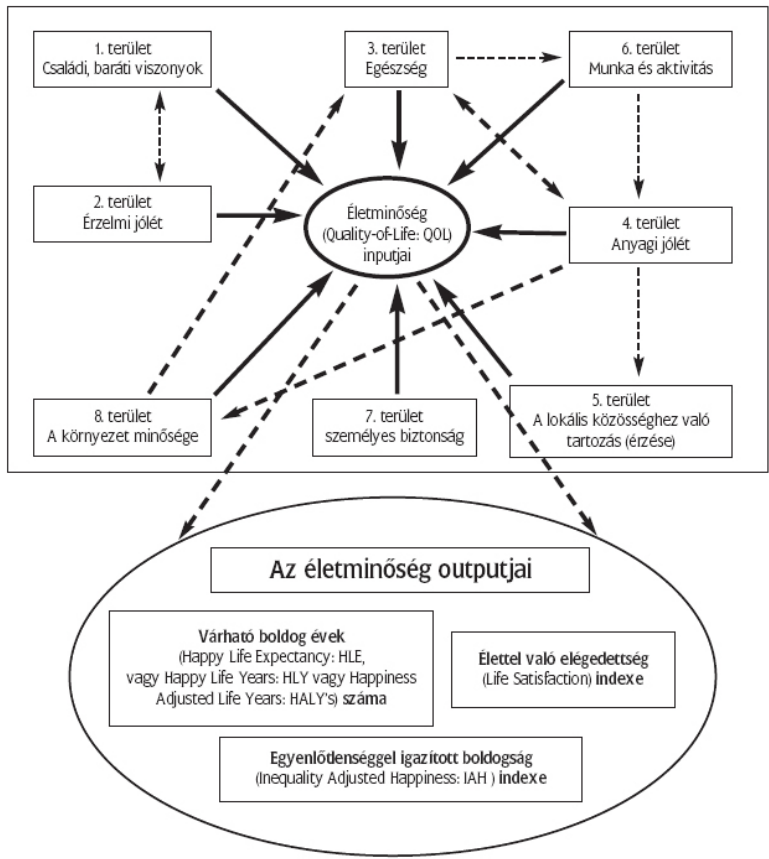

Forrás: Sebestyén 2005

2. ábra - A teljes Rahman modell. (Rahman et al.2005; Kovács, 2005).

A modellünk kialakítása során a nyolc részterületből hetet tudtunk lefedni a Háztartáspanel kérdőív kérdéseivel. Ezek az előző fejezetben már említett kérdéseket (az első modell huszonhárom kérdése), a mellékletben bemutatjuk. A második részterülethez - Érzelmi jólét - nem tudtunk szorosabban illeszkedő saját mérőpontot rendelni, így ezt kénytelenek voltunk kihagyni modellünkből.

Az egyes részterületeket fökomponens analízis segítségével vontuk össze. Az analízis során a hiányzó válaszokat a csoportátlaggal helyettesítettük - csökkentve így a kieső méréseket. Minden, több kérdésből álló csoport egy összevont értéket kapott az eljárás során ( $\mathrm{F} 1, \mathrm{~F} 3, \mathrm{~F} 5, \mathrm{~F} 6, \mathrm{~F} 7$ változók). Ezen változók súlyozva kerültek bevonásra az életminőség index kialakításakor. Azokban az esetekben, ahol csak egy kérdéssel mértük a részterületet, ott a súlyt egységnyinek vettük (egál1, ház26, illetve ház24 változók). 
Figyelemre méltó, hogy a 2008-as és 2010-es felmérés index-kialakító súlyszámai alig térnek el egymástól, pedig a két felmérés között időben két év és számos gazdasági, politikai, stb. változás következett be. -8 . táblázat.

2008: qli_fabian_takacs $=$

1.376 * F1 + 1 * egál1 + $1.007 * \mathrm{~F} 3+1 *$ ház26 + 1.710 * F5 + 1.471 * F6 + 1.718 * F7.

2010: qli_fabian_takacs $=$

$1.33 * \mathrm{~F} 1+1 *$ egál1 + $1.006 * \mathrm{~F} 3+1$ * ház $24+1.713 * \mathrm{~F} 5+1.428 * \mathrm{~F} 6+1.788 * \mathrm{~F} 7$.

8. táblázat - A qli_fabian_takacs életminőség index kialakítása.

A mindkét évre kialakított indexet hasonló vizsgálatoknak vetettük alá, mint, amit az első modellnél már bemutattunk. Ezen eredmények leírása szerepel a következő fejezetben.

\section{FÖKOMPONENS MODELL: 2008}

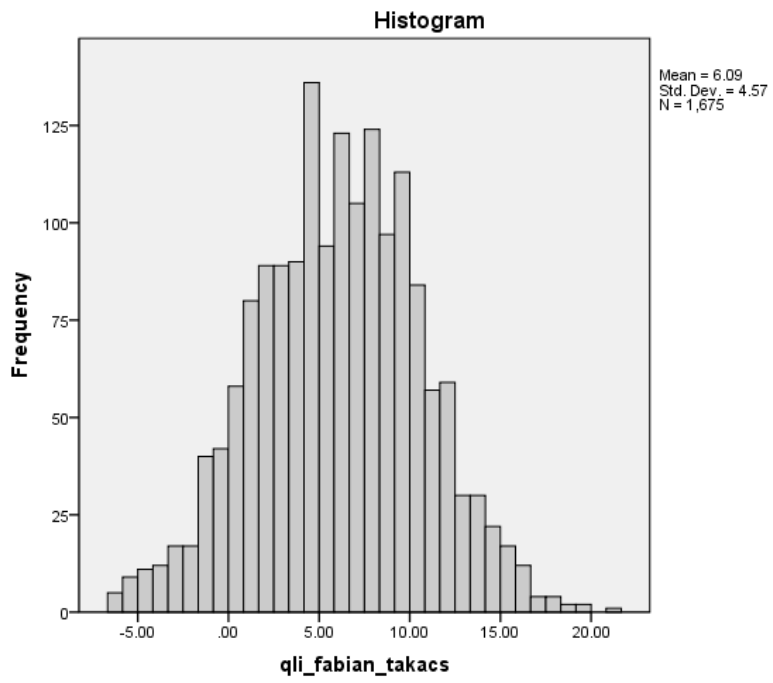

3. ábra - A qli_fabian_takacs életminőség index eloszlása a 2008-as adatok esetén.

A 2008-as modellben a bevont esetek száma: 1675; hiányzó, be nem vont esetek száma: 173. Az életminőség változó átlaga: 6,09. Az átlaghoz tartozó 95\%-os konfidenciaintervallum: 5,87-6,31. 5\%-os vágott átlag 6,09. Medián 6,16. Szórásnégyzet 20,89; szórás 4,57. Minimum érték -6,48, maximum érték 21,21. 
A normalitásvizsgálat normális eloszlásúnak mutatta az újonnan konstruált 2008-as életminőség változót. (Kolmogorov-Smirnov teszt: $\mathrm{p}=0,200$; Shapiro-Wilk teszt: $\mathrm{p}=0,253)$. 3. ábra.

A várt normalitás tehát igazolható a fökomponens alapú modellben, így nem kell azokkal a módszertani kérdésekkel szembenéznünk (paraméteres és nemparaméteres tesztek alkalmazhatósága), amelyekkel az egyszerübb Összegző modellnél már találkoztunk.

Kerületek. Az elemzések során követtük az első modell vizsgálati folyamatát, sorrendben először az „utca” (nyíregyházi városrészek, kerületek) változó szerinti életminőség megoszlást vizsgáltuk. 9. táblázat. A variancia-analízis eredménye szerint a kerületek nem rendelkeznek azonos életminőség átlagokkal $(\mathrm{p}=0,001)$. A post-hoc elemzés alapján a legalacsonyabb életminőség indexủ Huszártelep szignifikánsan az Örökösföld, Borbánya és Jósaváros II. területektöl tér el - 4. ábra.

\begin{tabular}{lllllllll} 
& & & & \multicolumn{7}{c}{$95 \%$ CI for Mean } \\
Oros & $\mathrm{N}$ & Mean & Std. Dev. & Std. Err. & Lower B. Upper B. & Min. & Max. \\
Örökösföld & 93 & 5.7332 & 5.46987 & .56720 & 4.6067 & 6.8597 & -6.48 & 19.18 \\
Sóstó & 183 & 6.7536 & 4.28220 & .31655 & 6.1291 & 7.3782 & -6.37 & 19.01 \\
Újkistelekiszõlõ & 114 & 6.4775 & 5.17707 & .48488 & 5.5169 & 7.4382 & -5.45 & 16.14 \\
Ókistelekiszõlõ & 9 & 6.8508 & 4.14290 & .56378 & 3.7200 & 5.9816 & -4.92 & 15.30 \\
Borbánya & 113 & 6.6867 & 4.34076 & 1.44692 & 2.6900 & 9.3632 & 0.74 & 12.30 \\
Huszártelep & 21 & 2.7844 & 4.17747 & .91160 & 0.8829 & 4.6860 & -4.89 & 10.08 \\
Kertváros & 97 & 6.6177 & 3.81097 & .38695 & 5.8496 & 7.3858 & -3.24 & 15.74 \\
Jósaváros I. & 183 & 5.6334 & 4.35847 & .32219 & 4.9977 & 6.2691 & -5.24 & 17.29 \\
Jósaváros II. & 51 & 7.4017 & 4.24682 & .59467 & 6.2073 & 8.5962 & -1.86 & 17.11 \\
Hímes & 46 & 6.4887 & 3.94039 & .58098 & 5.3185 & 7.6588 & -2.36 & 13.95 \\
Belváros & 497 & 5.6084 & 4.65951 & .20901 & 5.1977 & 6.0190 & -6.27 & 19.70 \\
Bokortanyák & 97 & 6.3099 & 4.58355 & .46539 & 5.3861 & 7.2337 & -5.17 & 21.21 \\
Nyírszõlõs & 60 & 6.2094 & 4.30301 & .55552 & 5.0978 & 7.3209 & -4.27 & 15.98 \\
Total & 1618 & 6.0313 & 4.57836 & .11382 & 5.8080 & 6.2545 & -6.48 & 21.21
\end{tabular}

9. táblázat - Az életminőség index kerületi átlagai 2008-ban.

(SPSS output: N - elemszám;Mean - átlag; Std. Dev. - Standard deviation, szórás; Std. Err. Standard Error, standard hiba; 95\% CI for Mean - az átlagra vonatkozó 95\%-os konfidencia-intervallum; Lower B., Upper B. - a konfidencia-intervallum alsó és felső határa; Min. - minimum; Max. - maximum).

Megjegyzés: Amennyiben a variancia-analízis eredménye szignifikáns eltérés mutat, kijelenthetjük, hogy a vizsgált csoportok középértékei nem egyenlőek, valamely csoport (vagy csoportok) lényegesen (szignifikánsan) eltérnek a többi csoporttól. Azt, hogy melyik csoport (vagy csoportok) különbözik csak egy újabb vizsgálat, az úgynevezett ,post hoc” analízis (utólagos analízis, páronkénti összehasonlítás) segít eldönteni. 


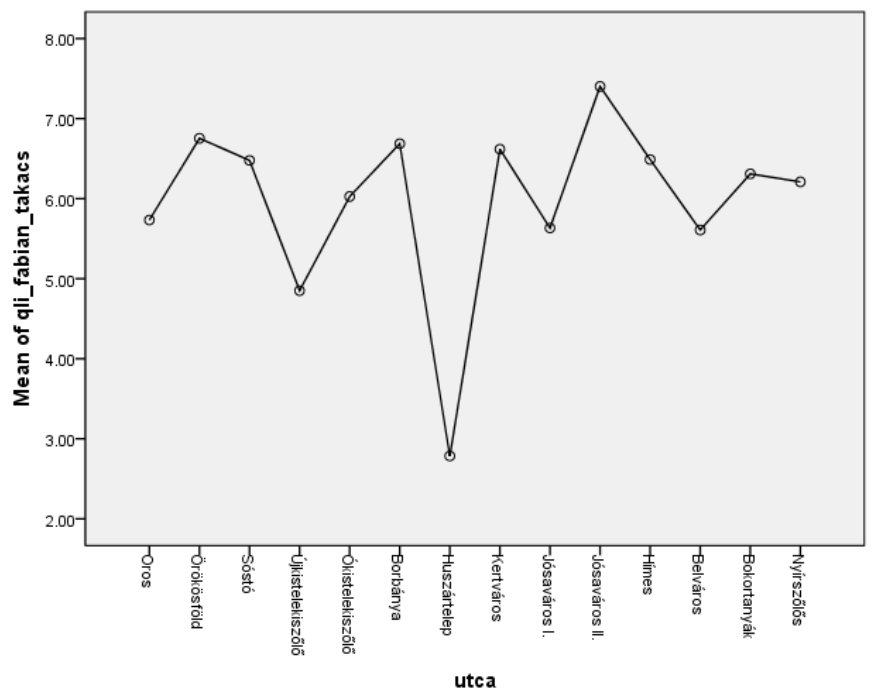

4. ábra - A qli_fabian_takacs életminőség index eloszlása a 2008-as adatok esetén.

Rétegek. A gazdasági vonatkozású megítélés („rétegek” változó) variancia-analízis vizsgálata egy réteget különített el élesen a többitől. Szignifikánsan magasabb az életminőség mutatója a szegény és alsó réteghez viszonyítva a felső közép-rétegnek és a jómódúak rétegének. A jómódúak életminőség indexe még a felső-közép-rétegtől is szignifikánsan magasabb ( $\mathrm{p}=0,000$; Tanhame post-hoc elemzés). 5 . ábra

Foglalkozás. A foglalkozás szerinti vizsgálat (gazd2 változó) szignifikáns különbséget jelez (variancia-analízis, $\mathrm{p}=0,000$, Scheffe post-hoc elemzés). Kiugróan alacsonyabb az életminőség mutatója a rokkantnyugdíjasoknak, a szociális segélyből élőknek és a munkanélküli, rendszeres szociális segélyt kapóknak.

Nyelvvizsgával rendelkezők esetén is a várt eredményt mutatták az elemzések. Kétmintás t-próba alapján kijelenthető, hogy a nyelvvizsgával rendelkezők életminőség mutatója (átlag: 8,85) szignifikánsan magasabb $(\mathrm{p}=0,000)$, mint a nyelvvizsgával nem rendelkezők mutatója (átlag: 5,49).

Autó. Hasonlóan az előző elemzéshez (kétmintás t-próba, $p=0,000$ ), az autóval rendelkezők lényegesen magasabb életminőség mutatót (átlag: 6,93) tudhatnak magukénak, mint az autóval nem rendelkezők (átlag: 4, 65). 


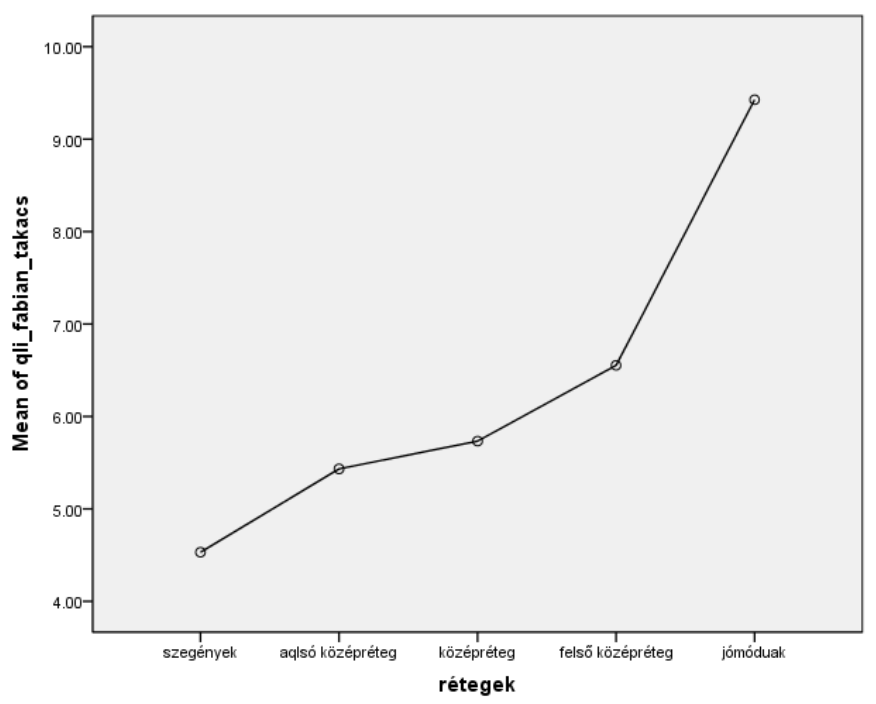

5. ábra - Az életminőség index átlagai a gazdasági rétegződés alapján - 2008.

\section{FÖKOMPONENS MODELL: 2010}

A bevont esetek száma: 476; hiányzó, be nem vont esetek száma: 584. Az életminőség változó átlaga: 5,77. Az átlaghoz tartozó 95\%-os konfidenciaintervallum: 5,38 - 6,15. $5 \%$-os vágott átlag 5,77. Medián 5,65. Szórásnégyzet 18,10; szórás 4,25. Minimum érték -10,82; maximum érték 18,68. A normalitásvizsgálat részben normális eloszlásúnak mutatta a 2010-es életminőség változót. (Kolmogorov-Smirnov teszt: $\mathrm{p}=0,161$; Shapiro-Wilk teszt: $\mathrm{p}=0,023)$. Ez utóbbi eredmény már figyelmeztet a bevonható esetek számának csökkenésére. A 2012-es vizsgálatok során fokozott figyelmet kell fordítani a megfelelő mintavételre, a minél nagyobb válaszadási arányra.

Utca. A 2010-es eredmények hasonló képet tükröznek mint a 2008-as eredmények. A városrészek életminőség megoszlása nem mutat homogén eloszlást $(\mathrm{p}=0,037)$. A kis elemszám miatt a variancia-analízis elvégzésekor ki kellett zárnunk az Ókistelekiszőlő terület eredményét ( $\mathrm{n}=1$, a kizárás után a variancia-analízis $\mathrm{p}$ értéke 0,025$)$. A szignifi kánsan alacsonyabb életminőség mutató megmaradt a Huszártelepen. Magas a mutató átlaga Oros, Örökösföld, JósavárosI. és Belváros területeken. Ezek az eredmények egy kicsit meglepőek, de az első modell tapasztalatait figyelembe véve, az elemszám növelése lenne kívánatos a pontosabb becslésekhez. 
Rétegek, foglalkozás, nyelvvizsga és gépkocsi. A további elemzések a hasonló képet mutatnak az eddigiekhez. A gazdasági vonatkozású megítélés (,rétegek” változó) variancia-analízis vizsgálata hasonlóan szignifikánsan a felső rétegek magasabb életminőségét tükrözi (variancia-analízis, $\mathrm{p}=0,000$ ). A foglalkozás vizsgálata szintén előhozza a már kimutatott különbségeket (variancia-analízis, $\mathrm{p}=0,000$ ). Figyelemfelkeltő tényező viszont az, hogy a 2008-as alacsonyabb kategóriákhoz csatlakozik 2010-ben a nyugdíjasok és a GYES-en, GYED-en lévők köre. Ennek (és számos más tényező megváltozásának) magyarázataként a gazdasági válság hatásit mindenképpen figyelembe kell vennünk. A nyelvvizsga és a gépkocsi birtoklása szintén hasonló képet mutat 2010-ben is, a vizsgált életminőség mutató vonatkozásában.

A 2008-as és 2010-es kerületi/utca adatok összevetése. A két vizsgálati évben a fökomponens modell paraméterei alig térnek el egymástól (lásd 6. ábra), így közvetlenül is lehetőségünk lenne összevetni az egyes életminőség átlagokat például a kerültek esetén. A pontosabb megközelítés viszont a standardizált értékek összehasonlítását követeli meg. A 6. ábrán ilyen standardizált életminőség mutatókból számított kerületi átlagokat láthatunk a vizsgált két év vonatkozásában. Szembetűnő egyes részeken az átla gos életminőségi értékek csökkenése, illetve növekedése. Az 10. táblázat összefoglalva tartalmazza az életminőség-átlag számszerủ változásait a kerületekben, sorrendbe szedve. A pozitív értékek csökkenést, a negatív értékek pedig emelkedést jeleznek (a számítás módja: 2008-as standardizált adatok - 2010-es standardizált adatok). Négy területen figyelhető meg életminőség emelkedés (Sóstó, Oros, Jósaváros I. és a Belváros). A többi tíz kerületben, viszont életminőség csökkenés tapasztalható. A legnagyobb csökkenés JósavárosII.-ben, Huszártelepen, a Bokortanyákon és Újkistelekiszőlőben. A változások magyarázata még további feladatokat ró ránk, de az egyértelmű, hogy a gazdasági változás mellett figyelembe kell vennünk a város belső migrációját is.

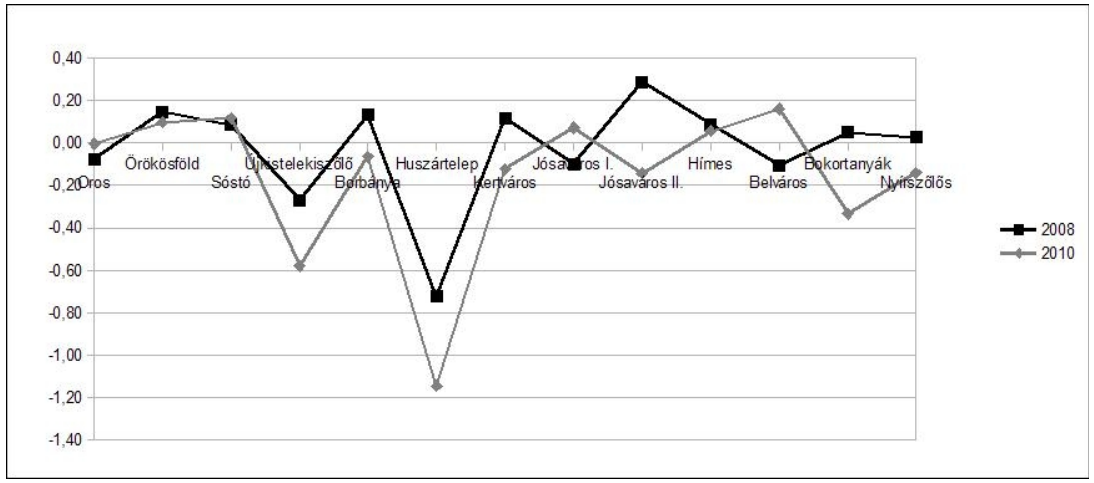

6. ábra - Az életminőség index standardizált értékei Nyíregyháza vizsgált kerületeiben, 2008-ban és 2010-ben. 


$\begin{array}{lcll}\text { 1. Jósaváros II. } & 0,4305975 & \text { 2. Huszártelep } & 0,4217368 \\ \text { 3. Bokortanyák } & 0,3824558 & \text { 4. Újkistelekiszõlõ } & 0,3081699 \\ \text { 5. Kertváros } & 0,2396256 & \text { 6. Borbánya } & 0,194972 \\ \text { 7. Nyírszõlõs } & 0,1662411 & \text { 8. Örökösföld } & 0,048028 \\ \text { 9. Hímes } & 0,0329456 & \text { 10. Sóstó } & -0,0314854 \\ \text { 11. Oros } & -0,0730713 & \text { 12. Jósaváros I. } & -0,1710844 \\ \text { 13. Belváros } & -0,2640916 & & \end{array}$

10. táblázat - Az életminőség index standardizált értékeinek változásai kerületek szerint (2008-2010).

A 2008-as és 2010-es rétegződési adatok összevetése. A két év standardizált adatokra épülő életminőségi átlagai társadalmi/gazdasági rétegződések alapján az 7. ábrán vannak ábrázolva. Feltűnő a jómódúak $(0,22)$ és a szegények $(0,19)$ életminőség csökkenése. A középréteg $(0,03)$ és az alsó középréteg $(-0,05)$ lényegében változatlan, a felső középréteg $(-0,19)$ viszont minőségibb életet élhet 2008-hoz képest 2010-ben.

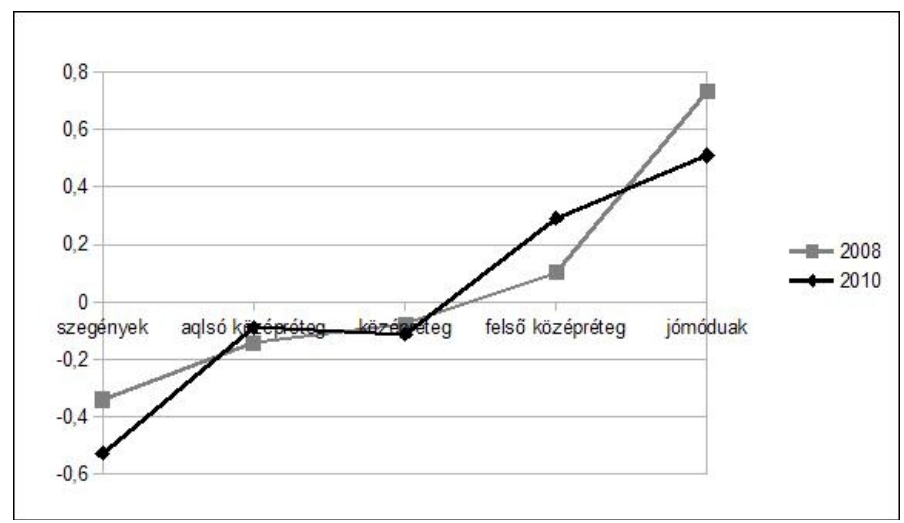

7. ábra - Az életminőség index standardizált értékeinek rétegbeli változásai (2008-2010).

\section{ÖSSZEFOGLALÁS}

Az előző fejezetekben részletes betekintést nyújtottunk Nyíregyháza Háztartáspanel vizsgálatára épülő életminőség kutatások aktuális eredményeibe.

A bemutatott modellek közül az első olyan kísérleti modell, amelynek további fejlesztéséröl le kellett mondanunk a bevont esetek nagyarányú csökkenése miatt. Mégis leszögezhetjük, hogy az alapvető tendenciák már ennek a modellnek a vizsgálatával is kimutathatók. Tükröződnek olyan elvárt tendenciák, mint a városrészek közötti életminőség különbségek, az eltérő gazdasági erővel bíró rétegek és a foglalkozás szerinti egyenlőtlenségek. Kimutatható már itt is a személygépkocsi tulajdonlás, mint a jómód egyik (jövőbeli?) reprezentánsa. 
A második modellt sokkal precízebbnek, statisztikai szempontból érettebbnek kell tekintenünk. A normalitás megjelenése a kialakított életminőség-index esetén lehetővé teszi erősebb statisztikai módszerek alkalmazását, amelyek megerősítik az első modellben már felbukkanó eredményeket. A Rahman modell nyolc részterülete közül az qli_fabian_takacs index hetet magába foglal, így elmondhatjuk, hogy sikerült az eredeti Rahman modellt egy „alacsonyabb”, „városi” szinten is feltölteni tartalommal, elemzési lehetőséget biztosítva a további kutatás és gyakorlati alkalmazás számára. A mutató alkalmasnak látszik olyan belső struktúrák és folyamatok feltárására, amelyek más mérési módokon nehezebben kimutathatók és értelmezhetők. Ezek elemzése és az eredmények értelmezése még folyamatban van, de kijelenthetjük, hogy a vizsgálatok már a két év összehasonlítása révén is hatással vannak a város életére, a városlakók életminőségének javulására.

\section{IRODALOM}

1. Székelyi M.- Barna I.(2005.): Túlélökészlet az SPSS-hez. Typotex Kiadó, Budapest,

2. T. Rahman-R. C. Mittelhammer- P. Wandschneider (2005.): Measuring the Quality of Life across Countries. Research Paper No. 2005/06. UNU-Wider

3. Kovács B.(2007.): Életminőség - boldogság - turizmusstratégia. Polgári Szemle, 2007. február. Hivatkozás: Sebestyén T. 2005b: Életminőség és boldogság magyar trendje vizsgálatok globális összehasonlításban. Eutrend $\mathrm{Ku}-$ tató. Budapest. (Kézirat)

4. Kovács B.-Horkay N.-Michalkó G. (2006.): A turizmussal összefüggő életminőség-index kidolgozásának alapjai. Turizmus Bulletin. X. 2.

http://itthon.hu/site/upload/mtrt/Turizmus_Bulletin/bulletin_2006_2/eletminoseg_index.html

MELLÉKLET - A 23 bevont modellépítő kérdés, és csoportosításuk:

\begin{tabular}{|c|c|c|c|}
\hline 2008 & 2010 & Kérdés & csoport \\
\hline társ 1 & társ2 & $\begin{array}{l}\text { Hány barátja van Önnek? } \\
0 \text { - nincs barátja } \\
98 \text { - nincs válasz } \\
99 \text { - nem tudja }\end{array}$ & I. \\
\hline társ13 & társ8 & $\begin{array}{l}\text { Milyen gyakran találkozik barátaival? } \\
1 \text { - mindennap } \\
2 \text { - 1-2 alkalommal hetente } \\
3 \text { - 1-2 - alkalommal havonta } \\
4 \text { - ritkábban,mint havonta } \\
5 \text { - soha }\end{array}$ & I. \\
\hline
\end{tabular}




\begin{tabular}{|c|c|c|c|}
\hline & & 99 - nincs válasz & \\
\hline társ13h2 & társ8h2 & $\begin{array}{l}\text { Milyen gyakran találkozik rokonaival? } \\
1 \text { - mindennap } \\
2-1-2 \text { alkalommal hetente } \\
3-1-2 \text { - alkalommal havonta } \\
4 \text { - ritkábban,mint havonta } \\
5 \text { - soha } \\
99 \text { - nincs válasz }\end{array}$ & I. \\
\hline egál1 & egál1 & $\begin{array}{l}\text { Hogyan jellemezné egészségi állapotát? } \\
1 \text { - nagyon jó } \\
2 \text { - jó } \\
3 \text { - elfogadható } \\
4 \text { - rossz } \\
5 \text { - nagyon rossz } \\
99 \text { - nincs válasz }\end{array}$ & III. \\
\hline ház26 & ház24 & $\begin{array}{l}\text { Mit mondana havi jövedelmére? } \\
1 \text { - csak nagy nehézségek árán jövünk ki belöle } \\
2 \text { - nehézségek árán jövünk ki belöle } \\
3 \text { - némi nehézség árán jövünk ki belőle } \\
4 \text { - kijövünk belöle } \\
5 \text { - viszonylag könnyen kijövünk belőle } \\
6 \text { - nagyon jól kijövünk belöle } \\
99 \text { - nincs válasz }\end{array}$ & IV. \\
\hline társ11 & társ6 & $\begin{array}{l}\text { Tagja-e sportklubnak? } \\
1 \text { - igen } \\
2 \text { - nem } \\
99 \text { - nincs válasz }\end{array}$ & V. \\
\hline társ $11 \mathrm{~h} 2$ & társ6h2 & $\begin{array}{l}\text { Tagja-e helyi, szomszédsági csoportnak? } \\
1 \text { - igen } \\
2 \text { - nem } \\
99 \text { - nincs válasz }\end{array}$ & V. \\
\hline társ11h3 & társ6h3 & $\begin{array}{l}\text { Tagja-e művészeti csoportnak? } \\
1 \text { - igen } \\
2 \text { - nem } \\
99 \text { - nincs válasz }\end{array}$ & V. \\
\hline társ11h4 & társ6h4 & $\begin{array}{l}\text { Tagja-e vallási közösségnek? } \\
1 \text { - igen } \\
2 \text { - nem } \\
99 \text { - nincs válasz }\end{array}$ & V. \\
\hline társ $11 \mathrm{~h} 5$ & társ6h5 & $\begin{array}{l}\text { Tagja-e hobby vagy szabadidős klubnak? } \\
1 \text { - igen } \\
2 \text { - nem } \\
99 \text { - nincs válasz }\end{array}$ & V. \\
\hline
\end{tabular}




\begin{tabular}{|c|c|c|c|}
\hline társ12 & társ 7 & $\begin{array}{l}\text { Milyen gyakran beszélget a szomszédaival? } \\
1 \text { - mindennap } \\
2 \text { - 1-2 alkalommal hetente } \\
3 \text { - 1-2 alkalommal havonta } \\
4 \text { - ritkábban, mint havonta } \\
5 \text { - soha } \\
99 \text { - nincs válasz }\end{array}$ & V. \\
\hline társ $28 \mathrm{~h} 3$ & társ 23 h3 & $\begin{array}{l}\text { Milyen gyakran találkozik barátaival presszóban, söröző- } \\
\text { ben, nyilvános helyen? } \\
1 \text { - hetente } \\
2 \text { - havonta } \\
3 \text { - évente néhányszor } \\
4 \text { - évente egyszer-kétszer } \\
5 \text { - ennél ritkábban, szinte soha } \\
99 \text { - nincs válasz }\end{array}$ & V. \\
\hline gazd1 & gazd1 & $\begin{array}{l}\text { Dolgozik-e ön jelenleg? } \\
1 \text { - igen } \\
2 \text { - nem } \\
99 \text { - nincs válasz }\end{array}$ & VI. \\
\hline $\operatorname{gazd} 25$ & gazd25 & $\begin{array}{l}\text { Mi jellemzi az ön fizetését? } \\
1 \text { - teljesen elégedetlen } \\
2 \text { - elégedetlen } \\
3 \text { - közepesen elégedett } \\
4 \text { - elégedett } \\
5 \text { - teljesen elégedett } \\
99 \text { - nincs válasz }\end{array}$ & VI. \\
\hline szocp1 & szocp1 & $\begin{array}{l}\text { családtag } \\
1 \text { - igen } \\
2 \text { - nem } \\
99 \text { - nincs válasz }\end{array}$ & VII. \\
\hline szocp $1 \mathrm{~h} 2$ & $\begin{array}{l}\text { szocp } 1 \mathrm{~h} \\
2\end{array}$ & $\begin{array}{l}\text { barátok } \\
1 \text { - igen } \\
2 \text { - nem } \\
99 \text { - nincs válasz }\end{array}$ & VII. \\
\hline szocp 1h3 & $\begin{array}{l}\text { szocp } 1 \mathrm{~h} \\
3\end{array}$ & $\begin{array}{l}\text { ismerősök } \\
1 \text { - igen } \\
2 \text { - nem } \\
99 \text { - nincs válasz }\end{array}$ & VII. \\
\hline szocp 1h4 & $\begin{array}{l}\text { szocp } 1 \mathrm{~h} \\
4\end{array}$ & $\begin{array}{l}\text { hivatal } \\
1 \text { - igen } \\
2 \text { - nem } \\
99 \text { - nincs válasz }\end{array}$ & VII. \\
\hline
\end{tabular}




\begin{tabular}{|c|c|c|c|}
\hline szocp $1 \mathrm{~h} 5$ & $\begin{array}{l}\text { szocp1h } \\
5\end{array}$ & $\begin{array}{l}\text { szociális szolgáltató } \\
1 \text { - igen } \\
2 \text { - nem } \\
99 \text { - nincs válasz }\end{array}$ & VII. \\
\hline ház19h3 & ház15h6 & $\begin{array}{l}\text { hangos, zavaró környezet } \\
1 \text { - igen } \\
2 \text { - nem } \\
99 \text { - nincs válasz }\end{array}$ & VIII. \\
\hline ház19h4 & ház15h3 & $\begin{array}{l}\text { sötét a környék, kevés a fény } \\
1 \text { - igen } \\
2 \text { - nem } \\
99 \text { - nincs válasz }\end{array}$ & VIII. \\
\hline ház19h8 & ház15h4 & $\begin{array}{l}\text { légszennyezés, vagy egyéb környezeti probléma } \\
1 \text { - igen } \\
2 \text { - nem } \\
99 \text { - nincs válasz }\end{array}$ & VIII. \\
\hline ház19h9 & ház15h8 & $\begin{array}{l}\text { vandalizmus, bünözés a lakókörnyezetben } \\
1 \text { - igen } \\
2 \text { - nem } \\
99 \text { - nincs válasz }\end{array}$ & VIII. \\
\hline
\end{tabular}

\section{Csoportok}

I. Családi, baráti viszonyok

II. Érzelmi jólét (nincs mérve)

III. Egészségi állapot

IV. Anyagi jólét

V. Lokális közösség

VI. Munka és aktivitás

VII. Személyes biztonság

VIII. Környezet minősége 